\title{
ІННОВАЦІЙНА СТРАТЕГІЯ УПРАВЛІНСЬКОЇ ДІЯЛЬНОСТІ СУЧАСНОГО КЕРІВНИКА В УМОВАХ СТАЛОГО РОЗВИТКУ СУСПІЛЬСТВА
}

У статті з'ясовано основні засади модернізації управлінської діяльності керівника інноваційного освітнього закладу в умовах сталого розвитку суспільства.

Ключові слова: управлінська діяльність, інноваційна стратегія.

В статье рассматриваются основные принщипы модернизации управляюшей деятельности руководителя инновационного образовательного учреждения в условиях стабильного развития общества.

Ключевые слова: управленческая деятельность, инновационная стратегия.

The article describes the main principles of modernization of management innovation leader of an educational institution in sustainable development of the society.

Key words: management, innovation strategy.

У Національній стратегії розвитку освіти в Україні на 2012-2021 роки зазначено, що освіта має формуватись адекватно сучасним інтеграційним і глобалізаційним процесам, вимогам переходу до постіндустріальної цивілізації, чим забезпечить стійкий рух і розвиток України в першій половині XXI століття, інтегрування національної системи освіти до європейського і світового освітнього простору.

При цьому важливого значення набуває модернізація структури, змісту й організації освіти на засадах компетентнісного підходу, переорієнтації змісту освіти на цілі сталого розвитку; формування здоров'язбережного середовища, екологізації освіти, валеологічної культури учасників навчальновиховного процесу; розвиток наукової та інноваційної діяльності в освіті, підвищення якості освіти на інноваційній основі.

Це змушує заклад освіти відмовитися від неефективних форм і методів навчання, оновлювати зміст навчального матеріалу, адаптуватись до нового замовлення на освіту, постійно тримати у полі зору власний імідж.

Мета статmi - виявити основні засади модернізації управлінської діяльності керівника інноваційного освітнього закладу в умовах сталого розвитку суспільства та перевірити їх ефективність в умовах експериментального закладу всеукраїнського рівня «Школи культури здоров'я».

Проблемам управлінської компетентності керівника на-вчального закладу присвячено роботи Л. Васильченко, Р. Вдовиченко, І. Гришиної, О. Мармази, Є. Павлютенкова, В. Пікельної та ін., які визначають іiі головним чином наявним рівнем професійної освіти, досвідом, індивідуальнопсихічними особливостями, мотивацією професійної діяльності й безперервної освіти, самовдосконаленням і рефлексією, рівнем творчого потенціалу $[1 ; 2 ; 3]$. Проте залишаються нерозв'язаними проблеми зміни стратегії керівної діяльності в умовах реформування освіти і сталого розвитку суспільства.

Стратегія - це комплексний план, що орієнтує заклад освіти не на сьогодення, а на перспективу. Метою стратегії $є$ забезпечення не стільки поточного успіху, скільки прискореного постійного розвитку закладу в умовах конкуренції, лідерства на ринку надання освітніх послуг [5].

Інноваційна стратегія - один із засобів досягнення метизакладу освіти, який відрізняється від інших засобів своєю новизною. Важлива ланка стратегічного планування - це формування стратегії та конкретних програм іiі реалізації у формі безперервного процесу [4, с. 165].

Ці засади покладено в основу управлінської стратегії розвитку інноваційного закладу Криворізької гімназії № 49 - експериментального закладу всеукраїнського рівня, дійсного члена Асоціації шкіл майбутнього.

Управління процесом формування професійної компетентності педагогічного колективу в умовах інноваційного закладу ми розглядаємо як взаємодію керівника і вчителя, що має своїм результатом цілеспрямований розвиток особистості педагога. Саме в конкретному педагогічному колективі відбувається його професійне становлення, а тому роботу керівника закладу освіти 3 формування професійної компетентності вчителів можна розглядати як складну динамічну і цілісну систему, що має свої цілі і завдання, зміст і структуру, форми і методи організації.

Необхідно також зазначити, що ця система є унікальною для кожної школи, оскільки призначена для розвитку професійної компетентності вчителів як окремих і неповторних індивідуальностей в умовах певного напрямку діяльності інноваційного закладу. Така система повинна передбачати, передовсім, визначення стану професійної готовності вчителів до інноваційної діяльності, иї результатів та рівня сформованості професійної компетентності педагога. На основі отриманих даних складається корекційна програма, яка й допомагає забезпечити формування професійної компетентності кожного вчителя на основі диференційованого та системного підходів до організації 
педагогічного процессу, з урахуванням індивідуальних особливостей і можливостей учителів, а також завдань конкретного навчального закладу.

При цьому слід урахувати такі засади: 1) забезпечувати розвиток і саморозвиток, навчання i самонавчання вчителя, виходячи 3 виявлення його індивідуальних особливостей як суб'єкта навчально-виховного процессу; 2) надавати кожному вчителеві, ураховуючи його здібності, інтереси, ціннісні орієнтації і суб'єктний досвід, можливість реалізувати себе в інноваційному освітньому середовищі; 3) зміст і методи обираються таким чином, щоб учитель мав можливість виявити вибірковість предметного матеріалу, технології навчання, певних моделей навчальної і виховної роботи в умовах інноваційного закладу; 4) визнання розмаїття змісту і форм навчального процессу, вибір яких повинен здійснювати вчитель (вихователь) з урахуванням мети розвитку кожної дитини; 5) розвиток індивідуальності вчителя, на основі створення необхідних умов для удосконалення його професійної компетентності.

На початку експериментальної діяльності нами був здійснений аналіз рівня готовності педагогічного колективу до інноваційної діяльності (за методиками: діагностика рівня саморозвитку в професійно-педагогічній діяльності (за Л. Бережновою), оцінювання рівня творчого потенціалу особистості (за Т. Морозовою), методика вивчення задоволеності вчителів своєю професією і роботою (за Н. Журіним та Є. Ільїним), оцінка професійної спрямованості особистості вчителя (за Є. Роговим), діагностика рівня емоційного вигоряння (за В. Бойком у модифікації Є. Ільїна), визначення мотивації в роботі вчителя за Херцбергом), який виявився в межах середнього (35,8\%) високого $(64,2 \%)$.

Отже, педагогічний колектив виявився психологічно налаштованим на розробку й запровадження інновацій у навчально-виховний процес закладу.

Показниками ефективності управління розвитком інноваційного закладу, а, відтак, процесом професійного становлення педагогічного колективу в умовах сталого розвитку суспільства ми вважаємо: а) високий рівень готовності педагогічного колективу до здійснення інноваційної діяльності; б) висока поінформованість вчителя про потенційно можливі нововведення в галузі освіти; в) виокремлення актуальних проблем для саморозвитку вчителя 3 питань інноваційної діяльності; г) реалістичність планів досягнення цілей саморозвитку; г) зацікавленість учителів в активному оволодінні новітніх технологій і самовдосконаленні своєї діяльності; д) високий рівень професійної компетентності вчителя; е) результативність роботи вчителя, що виявляється в підвищенні рівня вихованості й навченості учнів.

Ці засади покладено в основу запроваджених нами технологій управлінської діяльності в умовах експериментального закладу:

- функціональна технологія створення структурних підрозділів для здійснення експериментальної діяльності;

- технологія стратегічного програмно-цільового планування діяльності закладу нового типу;

- інформаційні технології моніторингу стану професійної компетентності педагогічного колективу.

Запровадження цих технологій у практику діяльності гімназії дало новий поштовх до розвитку інноваційного закладу: 1) розроблено концепцію діяльності на основі компетентнісного підходу та стратегічний план розвитку закладу; 2) створено науково-методичний центр, що об'єднує досвідчених учителів гімназії і науковців Криворізького національного університету; 3) розроблено діагностувальний рівень готовності педагогічного колективу до інноваційної діяльності; 4) розроблено діагностувальний рівень професійної компетентності вчителя; 5) здійснено діагностику особистісних якостей учителя 3 метою складання індивідуальних програм саморозвитку щодо вдосконалення професійної компетентності; 6) розроблено систему роботи з формування професійної компетентності вчителя, яка включає: аналіз і оцінку педагогічного досвіду вчителя; актуалізацію знань учителя 3 різних проблем і напрямів інноваційної діяльності; виконання творчих робіт; 7) запропоновано систему задач, педагогічних ситуацій, ділових ігор і соціально-психологічних тренінгів задля формування професійної компетентності вчителя; 8) розроблено рекомендації для вчителів і керівників методичних об’єднань щодо процесу формування професійної компетентності вчителя інноваційного закладу в умовах сталого розвитку суспільства.

Дослідження, проведені до та після реалізації зазначених засад управлінської діяльності керівника школи, виявили підвищення рівня готовності педагогічного колективу до здійснення інноваційної діяльності, рівня професійної компетентності кожного вчителя, що позитивно позначилося на освіченості і вихованості учнів гімназії.

Отже, найбільш важливими засадами інноваційної управлінської діяльності сучасного керівника в умовах сталого розвитку суспільства $\epsilon$ формування стратегії та конкретних програм іiі реалізації у формі безперервного процесу становлення професійної компетентності вчителя, особистісно орієнтований підхід до кожного педагога, формування в учителів усвідомлення особистої причетності до інноваційної діяльності закладу освіти на основі впровадження й урізноманітнення форм і методів професійної діяльності.

1. Васильченко Л. В. Управлінська культура і компетентність керівника / Л. В. Васильченко. - Х. : Вид. 
група «Основа», 2007. - 176 с. 2. Васильченко Л. В. Професійна компетентність керівника школи / Л. В. Васильченко, І. В. Гришина. - Х. : Вид. група «Основа», 2006. - 208 с. 3. Вдовиченко Р. П. Управлінська компетентність керівника школи / Р. П. Вдовиченко. - Х. : Вид. група «Основа», 2007. - 112 с. 4. Геник О. Особливості інноваційної стратегії організації вітчизняних підприємств / О. Геник // Формування ринкової економіки в Україні. - 2009. - Вип. 19. - С. 165-169. 5. Менеджмент організацій: підручник / за заг. ред. Л. І. Федулової. - К. : Либідь, 2004. - 448 с. 